Indonesian Journal of Theology 6/1 (July 2018): 83-104

\title{
MENALAR DILEMA ETIS DALAM FILM SILENCE
}

\begin{abstract}
Abel K. Aruan
Abstract

Silence was a provocative film, particularly for Christians viewers. Aside from sketching stories of great interest concerning challenges endured by Jesuit missionaries to Japan, the film presents a deep ethical struggle one finds worthy of careful analysis. In the most climactic scene, the missionary Rodrigues faces an ethical dilemma. He must desecrate fumi-e, a bronze board depicting Christ Jesus, in an act of apostasy to save five tortured and dying hostages. Rodrigues must choose: apostasy or allowing people to die. In this article, the author attempts to reason through Rodrigues' ethical dilemma, without providing conclusive arguments in support of any ethical choices the author might prefer, to broaden the thinking of his readers. Following preliminary considerations for how to define the category of ethical dilemma, the author provides two key questions for evaluating solutions belonging to the moral agent. $(\alpha)$ Concerning competing moral demands, which one is highest in standing amid the rest? $(\beta)$ Concerning available interventions by the moral agent, which action most effectively realizes the highest moral demand? These two lines of inquiry frame three proposed solutions. Finally, the author also proposes a fourth solution termed Kierkegaardian conflict, following the philosopher of ethics Phillip L. Quinn, whose own proposal, too, remains inconclusive for resolving the dilemma.
\end{abstract}

Keywords: Thomas Aquinas, Silence, Shusaku Endo, ethical dilemma, Kierkegaardian conflict, divine command theory

\begin{abstract}
Abstrak
Film Silence cukup mengundang respons dari orang-orang Kristen yang menontonnya. Selain karena film ini cukup menarik dalam menggambarkan perjuangan misionaris Jesuit di Jepang, ada pergumulan etis di dalamnya yang layak ditelaah secara mendalam. Misionaris Rodrigues dalam adegan paling klimaks di film diperhadapkan dengan sebuah dilema. Dia dipaksa menginjak fumie, sebuah papan tembaga bergambar Yesus Kristus, sebagai bentuk
\end{abstract}


pemurtadan demi menyelamatkan lima orang sandera yang tersiksa dan menderita. Rodrigues harus memilih: murtad atau membiarkan orang mati. Dalam artikel ini, penulis mencoba menalar dilema etis yang dialami oleh Rodrigues, tanpa memberikan kesimpulan tentang pilihan etis mana yang sedang dia bela, demi membuka pikiran pembaca lebih lebar. Melalui sebuah penalaran pendahuluan tentang definisi dilema etis, penulis memberikan dua pertanyaan kunci terhadap keterhimpitan yang dialami oleh seorang pelaku moral. $(\alpha)$ Tuntutan moral mana yang lebih utama di antara yang lain? $(\beta)$ Tindakan apa yang secara efektif dapat mewujudkan tuntutan moral tersebut? Dua pertanyaan itu menjadi parameter bagi tiga usulan pandangan. Di akhir, penulis juga memberikan usulan keempat yang dinamakan Kierkegaardian conflict dari seorang filsuf etika Philip L. Quinn, sebuah usulan yang tidak juga konklusif.

Kata-kata Kunci: Thomas Aquinas, Silence, Shusaku Endo, dilema etis, konflik Kierkegaardian, teori perintah ilahi

\section{Pendahuluan}

Pada tanggal 13 Januari 2017 lalu sebuah film yang dibintangi Andrew Garfield dan Adam Driver diluncurkan. Film tersebut meraih Box Office 7 juta dolar, yang bisa dikatakan terbilang kecil untuk ukuran tayangan Hollywood. Film ini memang kurang diminati oleh kalangan populer. Sinematografinya tak semegah Titanic. Plotnya pun tak secerdas seri The Fast and the Furious. Akan tetapi, film ini meraih 85\% tomatometer. ${ }^{1}$ Artinya film ini memang punya rating yang baik di kalangan kritikus. Martin Scorsese, sang sutradara, menamainya Silence. ${ }^{2}$ Silence adalah sebuah film dengan tema kekristenan yang sangat kental. Film ini bahkan berani mengisahkan pekerjaan murid-murid Kristus yang sangat sensitif bila dibicarakan dalam khalayak publik, yaitu gerakan misi penginjilan. Yang lebih menarik lagi, film ini tidak hanya mengisahkan perjalanan mengenai gerakan misi tersebut. Agaknya Martin, begitulah biasanya sutradara ini dipanggil, membangun kisah ini demi klimaks yang sudah disiapkan di 30 menit terakhir.

1 Tomatometer adalah rating untuk kritik yang diberikan oleh kalangan profesional di dunia perfilman. Bisa dibilang, pemberi komentar di situs rottentomatoes.com merupakan pegiat di dunia perfilman. Penilaian ini berbeda dengan penilaian penonton populer seperti yang ditampilkan situs-situs lainnya (https://www.rottentomatoes.com/about/). Sushaku Endo

${ }^{2}$ Film ini diadaptasi dari novel dengan judul yang sama yang ditulis oleh 
Dalam menit-menit itu ada sebuah dilema etis yang sangat kompleks dan hampir pasti menyebabkan pembicaraan panas pada siapapun yang sudah menontonnya. Paus Francis, misalnya, berkata, "Silence presents a textured, realistic Christian faith, and has the potential to build the faith of the devout and the skeptical alike, bearing fruit in the church's witness and mission in the world." 3 Kontras dengan itu, dalam situs The Christian Post Julie Roys menganggap bahwa film ini "[i]s pretty depressing and potentially disillusioning. Rather than exaltation, it features capitulation. And rather than inspiring, it simply deflates and confuses." 4 Tidak jelas memang apakah penolakan Roys berasal dari pilihan etis tokoh utama dalam film tersebut ataukah berasal dari intensi sutradara yang menghadirkan dilema tersebut. Yang pasti, apa yang menjadikan film ini kontroversial layak diulas secara mendalam.

Untuk mengulasnya, pertama-tama, saya memberikan sinopsis film ini terkait dengan materi-materi penting yang akan menjadi pertimbangan dan bahan diskusi. Ada alur kisah film yang dipaparkan, tetapi itu tidak mewakili semua detail. Namun bisa jadi itu tidak mewakili garis utama yang dikehendaki sutradara. Sinopsis dihadirkan hanya untuk mendukung tujuan penulisan artikel ini, yakni meninjau satu konflik moral yang terjadi di dalamnya. Kedua, saya juga memberikan beberapa definisi dilema etis demi membatasi telaah terhadap kasus di dalamnya. Terakhir, saya memaparkan beberapa usulan untuk mengurai dilema tragis tersebut. Beberapa pendekatan akan mendapatkan penilaian bahkan bantahan dari saya. Walaupun saya tidak akan secara jelas menjelaskan pilihan yang terbaik, akan tetapi diharapkan artikel ini dapat mengajukan perspektif mengenai tindakan-tindakan moral yang bisa jadi pilihan Rodrigues-tokoh yang berhadapan dengan dilema dalam film. Selain itu, paling tidak, pembaca bisa mendapatkan beberapa alternatif pendekatan yang menolong untuk melihat bahwa ini adalah sebuah pergumulan yang sulit tetapi bukan berarti tidak bisa dipecahkan.

3 Brett McCracken, "Scorsese's 'Silence' Asks What It Really Costs to Follow Jesus," Christianity Today, 16 Desember 2016, diakses 8 Mei 2017, http://www.christianitytoday.com/ct/2016/december-web-only/silence-whispersloudly-of-christs-love.html? start $=2$.

4 Julie Roys, "Why Are Christians Praising Scorsese's 'Silence'? (Movie Review)," Christian Post, 13 Januari 2017, diakses 8 Mei 2017, http://www.christianpost.com/news/christians-praising-scorsese-silence-moviereview-172951/. 


\section{Sinopsis Silence ${ }^{5}$}

Film ini dimulai dengan berita murtadnya seorang pastormisionaris Jesuit Christovao Ferreira. Awalnya, Bapa Ferreira merupakan orang yang cukup dihormati oleh masyarakat awam maupun murid-muridnya di kalangan Jesuit Portugal. Dia jugalah yang menginspirasi banyak biarawan untuk melakukan gerakan penginjilan ke tempat-tempat berbahaya, termasuk ke Jepang. Setelah memberikan pengaruh yang besar di Portugal, Bapa Ferreira berangkat ke Jepang dan melakukan perjalanan misi yang mengancam nyawa. Di sana hidupnya sangat mempengaruhi banyak orang Kristen-Jepang yang memegang iman secara sembunyi-sembunyi di setiap desa. Sayangnya, setelah beberapa lama, terdengarlah kabar pemurtadan tersebut. Kabar menyedihkan mengenai bapa mereka seketika menghebohkan gereja. Gerakan misi dari Portugal terancam mengendur.

Di Portugal, Fransisco Garrpe dan Sebastian Rodrigues, yang merupakan dua orang murid Bapa Ferreira, tidak percaya akan berita tersebut. Mereka menganggap bahwa tidak mungkin guru mereka bertingkah "seperti anjing di hadapan para kafir Jepang." Benar bahwa pemerintah Jepang saat itu sangat opresif terhadap umat percaya. Siksaan dan pembunuhan jelas menjadi ganjaran bagi yang tidak mau murtad. Akan tetapi, Garrpe dan Rodrigues yakin bahwa guru mereka tidak mungkin tidak dapat bertahan dalam tekanan dan siksaan sekeras apapun. Mereka kemudian berangkat ke Jepang melalui perjalanan yang melelahkan, beresiko, dan jelas merugikan. Dibantu oleh orangorang percaya yang bersembunyi, mereka berkeliling ke desa-desa untuk mencari Bapa Ferreira. Beberapa desa mengenal nama yang mereka tanyakan. Beberapa tidak. Agar proses pencarian berjalan lebih cepat, keduanya memutuskan untuk memisahkan diri. Bila Bapa Ferreira ditemukan tidak murtad, Garrpe dan Rodrigues berniat mengirimkan kabar gembira tersebut. Harapan mereka satu: bila gereja mendengar bahwa guru besar ini tidak murtad, gerakan penginjilan akan batal mengendur, dan bahkan mungkin akan semakin masif.

Rodrigues, yang diperankan oleh Andrew Garfield, menjadi tokoh utama setelah mereka memisahkan diri. Sembari menghadapi tekanan, bergerak secara bersembunyi, melihat beberapa pembunuhan terhadap penduduk Jepang-Kristen yang tidak mau murtad, serta ditangkap oleh tentara Jepang, akhirnya Rodrigues dipertemukan dengan Bapa Ferreira di sebuah kompleks kekaisaran Jepang. Sedihnya, kabar bahwa Bapa Ferreira murtad memang benar. Rodrigues terdiam, bertanya mengapa Tuhan membiarkan dan tidak menguatkan umat-

\footnotetext{
${ }^{5}$ Dibuat dari pengamatan penulis terhadap film ini.
} 
Nya, termasuk Bapa Ferreira, yang berjuang dalam tekanan di negara penuh siksaan ini.

Tentara Jepang punya cara yang jitu untuk membuat penduduk Jepang-Kristen murtad. ${ }^{6}$ Mereka mengenal betul sikap orang percaya pada waktu itu terhadap benda-benda bersimbol kekristenan. Mereka menggunakan fumie, semacam papan perunggu bergambar Yesus Kristus, dalam proses pemaksaan untuk murtad. Penduduk JepangKristen yang ditemukan oleh tentara Jepang diharuskan untuk menginjak fumie yang ditaruh di tanah sebagai bentuk pemurtadan. Bila mereka menginjaknya, hukuman mati terhindarkan. Tentunya menginjak wajah Penebus mereka adalah hal yang sangat menyakitkan bagi kaum Kristen-Jepang. Tak hanya itu, bila tentara Jepang masih tidak percaya bahwa pemurtadan itu otentik, mereka akan menyuguhkan pahatan Yesus Kristus di kayu salib, lalu meminta penduduk Jepang-Kristen meludahinya. Jelaslah rasa bersalah yang besar akan timbul bila mereka meludahi wajah Yesus yang disalib demi bertahan hidup. Banyak dari antara mereka menginjak fumie dan meludahi salib. Beberapa tidak melakukannya. Hasilnya, ditenggelamkan, digantung, atau dipancung menjadi konsekuensi dari keteguhan iman tersebut. Tak disangka, kisah kematian mereka justru menjadi kesaksian bagi penduduk Jepang-Kristen lainnya. Pemerintah Jepang, akhirnya, memikirkan cara yang lain.

Pemerintah saat itu melihat bahwa kematian orang yang menolak murtad justru akan menjadi kesaksian bagi pengikut Kristus di Jepang. Selain para penduduk Jepang-Kristen akan semakin teguh memegang iman mereka, gerakan penginjilan dari Portugal menjadi semakin besar. Solusi baru yang mereka temukan adalah mengendurkan iman dan gerakan penginjilan melalui murtadnya pemimpin mereka. Bila umat melihat pemimpin mereka murtad, pikirnya, maka tidak ada lagi alasan yang kuat untuk juga memegang teguh iman.

Mereka punya trik tersendiri untuk memurtadkan para pemimpin umat. Untuk beberapa pemimpin rohani, mereka memberikan tekanan yang baru, yaitu perintah murtad demi menyelamatkan nyawa orang lain, bukannya nyawa sendiri. Bila seorang pemimpin umat dari Portugal tidak mau murtad, maka beberapa orang Jepang-Kristen akan dibunuh. Rodrigues juga sudah pernah melihat, di adegan sebelumnya, bahwa Garrpe, teman seperjalanannya, ditangkap dan dipaksa murtad dengan ancaman tentara Jepang akan menenggelamkan beberapa penduduk JepangKristen. Dalam adegan tersebut, Rodrigues hanya bisa berteriak dari

\footnotetext{
${ }^{6}$ Saya menggunakan istilah "Jepang-Kristen" untuk mewakili penduduk asli Jepang yang telah menjadi Kristen dan sedang dalam tekanan penganiayaan.
} 
kejauhan kepada Garrpe untuk murtad demi keselamatan nyawa pengikut mereka. Sayangnya, teriakan itu tak didengar. Garrpe teguh pada imannya. Beberapa penduduk Jepang-Kristen akhirnya mati tenggelam-bersama Garrpe yang berusaha menyelamatkan mereka. Melihat tragedi itu, Rodrigues berada dalam penyesalan besar dalam mengikut Tuhan. Dia menganggap Tuhan diam saja melihat penyiksaan yang dialami umat-Nya di Jepang. Tuhan tidak memberikan solusi pada dilema yang dialami Garrpe, sehingga akhirnya umat Jepang-Kristen mati. Tuhan seakan diam terhadap umat-Nya yang sedang berjuang dalam dilema-dilema tersebut. God is silent.

Klimaks di 30 menit akhir dari film ini membawa Rodrigues pada kondisi yang sama dengan yang pernah dialami oleh GarrpeBapa Ferreira murtad dengan tekanan dilematis yang serupa. Rodrigues akhirnya diperhadapkan dengan dua pilihan: dia harus murtad atau lima umat Jepang-Kristen akan mati tersiksa. Sebenarnya kelima penduduk tersebut sudah murtad, tetapi pemerintah Jepang tidak melepaskan mereka sampai Rodrigues sendiri yang murtad. Mereka tidak hanya langsung dibunuh, tetapi digantung terbalik dengan goresan pisau di belakang telinga. Darah akan menetes bersamaan dengan erangan rasa sakit, hingga akhirnya dalam waktu yang tidak singkat mereka tiba pada kematian. Dalam situasi ini, Rodrigues diminta untuk menyelamatkan mereka dengan cara murtad. Untuk lebih jelasnya, saya memberikan detail situasi dan kondisi (state of affair) yang dialami Rodrigues:

(1) Tawanan adalah kelima penduduk Jepang-Kristen yang digantung terbalik dengan darah yang mengucur dari leher perlahan-lahan. Dalam kondisi tersebut, mereka tidak akan mati dalam waktu beberapa hari. Yang ada adalah rasa sakit yang menyiksa di setiap tetes darah yang keluar.

(2) Kelima tawanan tersebut sudah murtad beberapa kali. Namun pemerintah Jepang tetap tidak melepaskan mereka dari gantungan.

(3) Tawanan yang tergantung hanya akan dilepaskan bila Rodrigues menginjak fumie sebagai bentuk pemurtadan.

(4) Pemerintah Jepang sempat mengatakan, "ini hanya formalitas." Mereka mengejar aksi yang bisa dilihat dan diberitakan ke seluruh Jepang.

(5) Bagi Rodrigues dan hampir semua orang percaya waktu itu, menginjak fumie berarti murtad.

(6) Rodrigues juga sadar bahwa dengan menginjak fumie dia telah memberitahukan pada penduduk Jepang-Kristen dan seluruh penduduk Jepang yang belum percaya bahwa seorang imam telah murtad lagi. 
(7) Tidak ada cara untuk melawan dan kabur, sebab aksi pemurtadan itu dijaga oleh algojo-algojo bersenjata pedang. Melawan berarti mati, baik bagi Rodrigues maupun kelima tawanan.

(8) Dalam banyak kesempatan dalam film tersebut, pemerintah Jepang selalu memegang janji mereka. Selama pemerintah melihat murtadnya otentik, siapapun akan dilepaskan sesuai yang dijanjikan.

(9) Bapa Ferreira berkata kepada Rodrigues, "Bila Yesus ada di sini, dia juga akan murtad demi menyelamatkan nyawa mereka."

(10) Dua tindakan terbaik yang mungkin dipilih Rodrigues adalah menginjak fumie atau tidak menginjak. Tindakan di luar kedua itu akan berdampak sama dengan (7). ${ }^{7}$

Dilema etis yang dialami Rodrigues terkurung dalam situasi demikian. Karena itu, setiap pertimbangan-pertimbangan yang muncul untuk menjawab dilema ini tidak boleh terlepas dari prasyarat kondisi yang sudah dipaparkan di atas.

\section{Definisi Dilema Etis}

Sebagaimana yang saya telah jelaskan di atas, kita perlu memikirkan terlebih dahulu apa definisi dilema etis, sehingga kemudian kita bisa mengatakan bahwa apa yang dialami Rodrigues dalam situasi tersebut di atas benar-benar merupakan sebuah dilema. Dalam sebuah artikel berjudul "Consistency in Rationalist Moral Systems," Alan Donagan menunjukkan pemaparan Thomas Aquinas mengenai usulan dilema moral yang ia setujui. Donagan mengartikulasikannya sebagai berikut: ${ }^{8}$

\footnotetext{
7 Saya memaparkan kondisi sebaik mungkin karena setiap pilihan-pilihan etis selalu berada dalam ruang dan waktu. Karena itu, kondisi menjadi penting untuk diketahui. Andrew Hoffecker berkata, "Kita tidak pernah membuat pilihan-pilihan etis dalam kevakuman. Setiap keputusan terjadi dalam suatu konteks historis yang kompleks....Semakin baik kita memahami kerumitan berbagai situasi kita dalam kehidupan, semakin tajam kita dapat menerapkan hukum-hukum Allah pada pengalaman kita....Kita dapat menerapkan norma-norma Allah pada situasi-situasi kita dengan jaminan yang mendasar bahwa Allah secara berdaulat bekerja untuk menghasilkan berbagai konsekuensi yang baik bagi kehidupan orang-orang yang mengasihi Dia." Andrew Hoffecker dan Gary Scott Smith, Membangun Wawasan Dunia Kristen, vol. 2, terj., Peter Suwadi Wong (Surabaya: Momentum, 2014), 416418.

8 Alan Donagan, "Consistency in Rationalist Moral Systems," Journal of Philosophy, Vol. 81 (1984): 306; dengan parafrase Quinn, dalam Philip L. Quinn, "Tragic Dilemmas, Suffering Love, and Christian Life," in Essays in the Philosophy of
} 
A.1 A system allows perplexity (or conflict of duties) ... if and only if situations to which it applies are possible in which, as result of violating one or more of its precepts, somebody would find that there is a precept he can obey only if he violates another.

Ada dua hal yang bisa ditelaah dari definisi Aquinas. Pertama, dilema moral hanya muncul jika dalam sebuah tuntutan moral seseorang harus melanggar tuntutan moral lain. Kedua, dilema dengan bentuk demikian muncul hanya karena sebelumnya sebuah/banyak tuntutan moral telah dilanggar.

Bila apa yang dihadapi Rodrigues merupakan dilema moral, maka, menurut definisi Aquinas, Rodrigues diasumsikan telah melakukan satu atau lebih pelanggaran moral yang membawanya pada dilema moral. Apa yang muncul di hadapan Rodrigues hanyalah sebuah konsekuensi dari kesalahannya sendiri. Bila demikian, Aquinas, menurut saya, seakan mengatakan bahwa sebenarnya seseorang tidak akan pernah benar-benar menghadapi dilema moral. Dia hanya menerima konsekuensi dari pelanggarannya sendiri.

Akan tetapi, yang terjadi tidaklah demikian. Dalam kasus Rodrigues, pemerintah Jepang menjadi pihak yang menyebabkan Rodrigues terjepit dalam situasi tersebut. Mereka sudah merencanakan situasi pemurtadan yang harus dilalui Rodrigues. Dari kondisi (4) dan (6) dapatlah diketahui bahwa pemerintah Jepang berinisiatif untuk menggembosi pergerakan misi dari Portugal dengan cara memurtadkan bapa-bapa utusan Portugal serta menggembosi iman orang-orang Jepang-Kristen dengan cara menyampaikan kabar mengenai prosesi pemurtadan itu.

Dalam kasus pada umumnya, memang benar bahwa ada pelanggaran-pelanggaran moral tertentu yang mengakibatkan seseorang tiba pada dilema moral baru. Namun, tidak semua dilema moral memiliki preseden pelanggaran moral. Bila Aquinas memaksudkan bahwa akar dari dilema moral adalah dosa manusia yang dari dulu sudah ada—dengan ini dia merujuk pada dosa Adam yang mengakibatkan kejatuhan kualitas dunia-maka definisi itu sedikit banyak masih bisa diterima secara teologis. Akan tetapi, Donagan tidak mengartikan demikian dari definisi yang diusulkan Aquinas. Menurutnya, semua dilema etis adalah akibat langsung dari pelanggaran moral tertentu. Andai Aquinas benar-benar mendukung penuh definisi itu, selain karena ketidakbergunaannya terhadap situasi Rodrigues, saya melihat absurditas definisi ini bila diterapkan pada setiap dilema moral

Religion, ed., Christian B. Miller (Oxford: Oxford University Press, 2006), 113. Quinn mengganti "perplexity" dengan "conflict," "precept" dengan "demand." 
yang pernah dialami manusia. Secara otomatis saya juga menolak definisi ini.

Definisi lain muncul dari Philip Quinn. Quinn berkata, "There is an ethical dilemma when a person is subject to two ethical demands such that he cannot satistfy both and neither demand is overridden or nullified." Dalam kalimat lain Quinn berkata, "When one confronts two conflicting ethical demands both of which are in force, one is caught in an ethical dilemma." 10 Proposisi berikut mungkin bisa merangkumnya:

A2. Sebuah dilema etis adalah keadaan di mana seseorang menemui dua tuntutan etis yang saling berkonflik di mana dia tidak bisa memenuhi keduanya sekaligus atau menghilangkan keduanya.

Dengan kata lain, dilema etis terjadi bila beberapa syarat yang terangkum dalam definisi tersebut terpenuhi. Rodrigues, misalnya, berada dalam dilema moral, bila dalam situasi seperti yang tertera dalam (1) - (10), dia menemukan dua tuntutan etis, yakni menyangkal atau tidak menyangkal Yesus di hadapan manusia, di mana keduanya saling berkontradiksi dan Rodrigues tidak bisa memenuhi atau menghilangkan keduanya sekaligus. Rodrigues hanya bisa memilih salah satu dari kedua tuntutan tersebut.

Definisi Quinn memaparkan syarat yang sangat detail, yaitu adanya dua tuntutan etis yang saling berkonflik, adanya kondisi yang tidak memungkinkan dia memenuhi keduanya dalam waktu yang sama, dan tidak memungkinkan untuk menolaknya dalam waktu yang sama juga. Bila semua syarat tersebut terpenuhi, maka seseorang bertanggung jawab terhadap salah satu dari kedua tuntutan moral yang diabaikannya. Yang menjadi pertanyaan tersisa adalah: tuntutantuntutan moral manakah yang akan berkonflik ketika seseorang berada dalam kondisi yang menjepitnya dalam-yang katanya-dilema etis? Dalam kasus Rodrigues, bisa saja seseorang menganggap bahwa kedua tuntutan yang muncul adalah penyangkalan terhadap Yesus untuk menyelamatkan orang lain dan larangan untuk menyangkal Yesus. Yang lain bisa juga berkata bahwa tuntutannya adalah menyangkal Yesus dan membiarkan orang lain mati. Bisa juga kedua tuntutan yang saling berkonflik itu adalah keharusan untuk menyelamatkan nyawa orang lain dan keharusan untuk mengakui iman kepada Yesus di hadapan manusia.

Di tahun yang sama dengan munculnya pendapat Quinn (1989), Norman Geisler memberikan pandangan yang bisa melengkapi

\footnotetext{
${ }^{9}$ Quinn, “Tragic Dilemmas, Suffering Love, and Christian Life," 110.

${ }^{10}$ Ibid.
} 
definisi Quinn. Geisler memang tidak memberikan definisi sejelas Quinn. Dalam buku Etika Kristen yang ditulisnya, tersuratlah definisi yang dibuat Geisler berdasarkan kesimpulannya dari beberapa kisah Alkitab. "Beberapa konflik moral yang secara pribadi tidak dapat dielakkan terjadi ketika seorang individu tidak bisa menaati kedua perintah" sekaligus. ${ }^{11}$ Secara sederhana, Geisler melihat bahwa konflik moral, atau dilema etis, muncul ketika seseorang tidak bisa menaati kedua perintah. Syarat "tidak bisa menaati kedua perintah" sudah masuk dalam definisi Quinn, yang nampak pada frasa "that cannot satisfy both." Lalu mengenai mana perintah yang berlaku, Geisler dapat menjawab bahwa itu ditentukan oleh situasi. Akan tetapi, menurut saya situasi tidak mengharuskan pelaku etis menunjukkan mana pilihan yang benar. Situasi hanya membantu menemukan apa saja tuntutan moral yang muncul dan menjadi pilihan untuk ditaati. Masalah mengenai mana tuntutan yang lebih tinggi, para pemikir moral masih harus mencarinya. ${ }^{12}$

Hal yang perlu disoroti dari definisi Quinn adalah frasa "dua tuntutan etis." Di sini saya melihat adanya perbedaan antara tindakan moral (moral action) dengan tuntutan moral/etis (moral/ethical demands). Dilema etis, secara kasat mata, ditunjukkan dengan adanya dua atau lebih pilihan tindakan moral yang tidak bisa dipenuhi secara bersamaan. Tindakan moral tersebut bukan cuma ditemukan dari situasi, tetapi konflik dari kedua tindakan moral tersebut adalah situasi itu sendiri. Dalam kasus Rodrigues, hal ini terlihat dari kondisi (10). Rodrigues hanya punya dua pilihan tindakan moral terbaik, apakah dia menginjak fumie atau tidak menginjak fumie. Di sisi lain, tuntutan moral terjadi bila ada dua pilihan hukum atau peraturan yang berkonflik, bukan dua pilihan tindakan. Apa yang bisa ditemukan oleh telaah situasi bukan cuma pilihan tindakan moral, melainkan juga beberapa pilihan tuntutan moral yang berlaku. Oleh karena itu, frasa "dilema etis" hendaknya tidak berhenti disematkan pada kedua tindakan moral yang bertentangan, melainkan juga disematkan pada tuntutan-tuntutan moral yang mendasari sebuah tindakan moral tertentu. Perhatikan bagan berikut.

${ }^{11}$ Norman Geisler, Etika Kristen: Pilihan dan Isu Kontemporer, ed. ke-2, terj., Ina Elia (Malang: Literatur SAAT, 2015), 121.

${ }^{12}$ Norman Geisler dan Paul D. Feinberg, Filsafat dari Perspektif Kristiani, terj., Tim Gandum Mas (Malang: Gandum Mas, 2002), 476. 


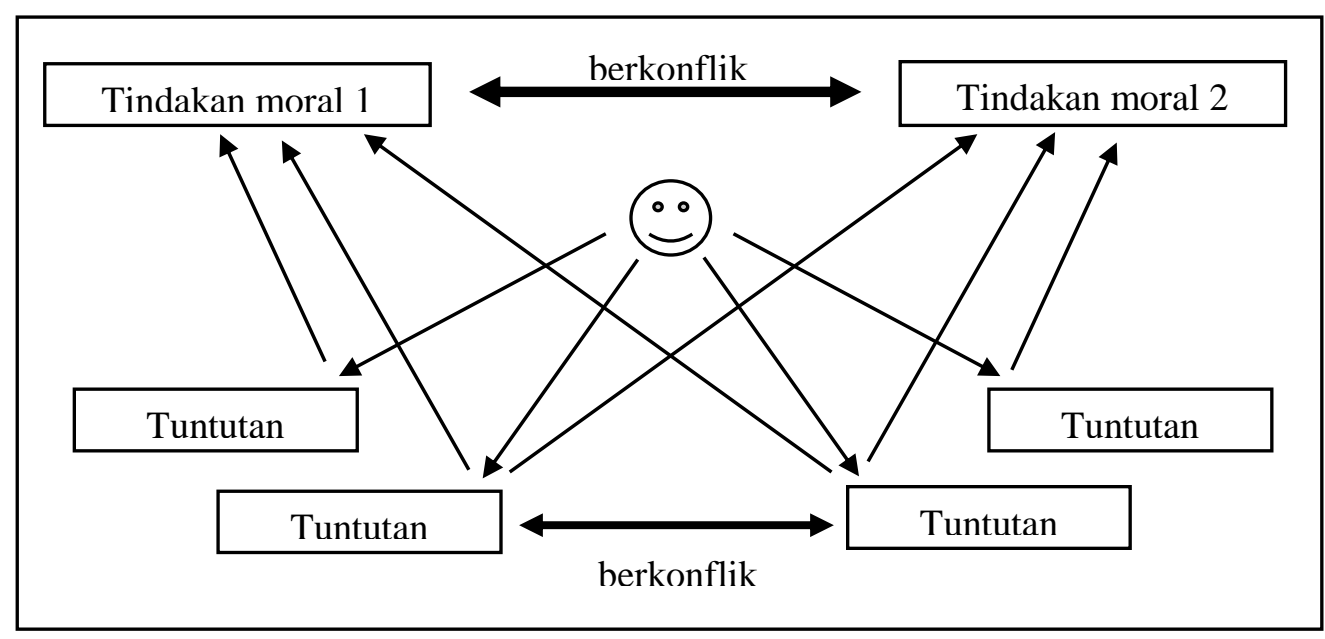

Secara kasat mata, tindakan moral 1 berkonflik dengan tindakan moral 2. Akan tetapi, seseorang yang menghadapi dilema etis tidak bisa dihakimi berdasarkan tindakan yang dia ambil saja. Dia juga harus dihakimi berdasarkan tindakan sekaligus dasar dari tindakan tersebut, yakni tuntutan moral. Misalnya, seseorang bisa saja mengambil tindakan moral 1 dengan pilihan dua dasar tuntutan moral yang berbeda (tuntutan moral 2 atau 3). Untuk itu, dia harus mampu melihat mana tuntutan moral yang lebih utama dari antara tuntutan moral 2 dan 3. Masalah menjadi berbeda ketika setelah dengan mudah menentukan tuntutan moral yang lebih penting (misalnya tuntutan moral 3) seseorang mencari tindakan moral yang efektif untuk mewujudkan itu (antara tindakan moral 1 dan 2). Karena itu, dua pertanyaan penting yang harus diajukan kepada siapapun yang sedang menyelesaikan dilema etis:

$(\alpha)$ Tuntutan moral mana yang lebih utama di antara yang lain?

( $\beta$ ) Tindakan apa yang secara efektif dapat mewujudkan tuntutan moral tersebut?

Hampir semua usulan-usulan berikut merepresentasikan jawaban atas salah satu atau kedua pertanyaan di atas.

\section{Jawaban-jawaban bagi Rodrigues}

Pertama, ada anggapan bahwa tindakan Rodrigues sebenarnya bisa dilihat sebagai sebuah tragedi yang tak perlu. Kondisi (4) menunjukkan bahwa Rodrigues bisa acting menginjak fumie tanpa 
melakukan pemurtadan. Bisa saja dia melakukan itu sesuai dengan perkataan pemerintah Jepang, yaitu sebagai formalitas. Karena itu, situasi tersebut tidak perlu dianggap sebagai tragedi konflik moral. Rodrigues juga tidak perlu ragu menginjak dan tidak perlu merasa bersalah. ${ }^{13}$ Akan tetapi jawaban tersebut tidak melihat otentisitas hati Rodrigues dalam kasusnya. Kondisi (5) juga menunjukkan bahwa Rodrigues sendiri sadar bahwa menginjak fumie adalah bentuk pemurtadan. Rasa bersalah yang dimunculkan di akhir film itu adalah konsekuensi dari apa yang dipercaya Rodrigues. Dia tahu betul bahwa menginjak fumie berarti murtad. Bila saja Rodrigues menginjak fumie dengan dasar formalitas, maka dia sedang berdusta. Dia bersembunyi dibalik anggapan pemerintah Jepang tersebut. Dengan demikian, dia tidak sedang menampilkan diri yang otentik ketika mengambil keputusan moral. Padahal, mengacu pada triade Hoffecker, seseorang bisa saja mengambil keputusan etis dengan "tidak melakukan . . a apa yang diketahuinya sebagai hal yang benar," dan itu dianggap sebuah pelanggaran etis. ${ }^{14}$ Seseorang haruslah mengambil keputusan etis dengan seluruh keberadaannya yang otentik. Keberadaan tersebut dideskripsikan oleh perangkat-etis (ethical faculty) —John Frame juga menyebutnya organ moral-yang ada pada seseorang, yaitu antara lain adalah hati, kesadaran, pengalaman, rasio, kehendak, imajinasi, emosi, dan yang lainnya. ${ }^{15}$ Semuanya harus bekerja secara otentik.

Selanjutnya, anggapan bahwa ini adalah tragedi yang tidak perlu juga muncul dengan argumen bahwa Pemerintah Jepang-lah yang memegang beban tanggung jawab tersebut. Rodrigues tidak perlu menganggap dirinya bertanggung jawab terhadap matinya kelima tawanan. ${ }^{16}$ Baik pertanyaan $\alpha$ maupun $\beta$ tidak akan dijawab oleh siapapun yang mengusulkan anggapan ini. $(\alpha)$ Tuntutan moral mana yang lebih utama di antara yang lain? Tidak ada, sebab ini bukan tanggung jawab Rodrigues. $(\beta)$ Tindakan apa yang secara efektif dapat mewujudkan tuntutan moral tersebut? Tidak ada, sebab memang tidak ada tuntutan moral yang harus diwujudkan dalam tindakan tertentu.

Sayangnya solusi ini tidak memperhatikan jelas definisi dilema etis. Seperti yang sudah dipaparkan di atas,

A2. Sebuah dilema etis adalah keadaan di mana seseorang, dalam situasi tertentu menemui dua tuntutan etis yang saling

\footnotetext{
${ }^{13}$ Quinn, "Tragic Dilemmas, Suffering Love, and Christian Life," 107.

${ }^{14}$ Hoffecker dan Smith, Membangun Wawasan Dunia Kristen, 418.

15 John M. Frame, The Doctrine of the Christian Life, A Theology of Lordship 3 (Phillipsburg: P \& R, 2008), 361-375.

${ }^{16}$ Quinn, "Tragic Dilemmas, Suffering Love, and Christian Life," 109.
} 
berkonflik di mana dia tidak bisa memenuhi keduanya atau menghilangkan keduanya.

Bila syarat itu dipenuhi, maka seseorang bertanggung jawab untuk memilih salah satu di antaranya. Karena itu, anggapan bahwa Rodrigues tidak perlu merasa bertanggung jawab adalah salah. Tanggung jawab diambil dari tindakan yang dihasilkan pada situasi yang seketika itu juga menimpa, bukan oleh penyebab-penyebab prasituasi. Dia tetap bertanggung jawab dalam kurungan spasial dan temporal. Bila batasan situasi bisa dipersalahkan demi menghilangkan tanggung jawab, maka tidak ada lagi syarat yang menyebabkan seseorang bertanggung jawab untuk pilihan etisnya. Semua bisa saja menyalahkan orang lain, situasi, alam, bahkan Tuhan.

Kedua, ketimbang menghindarkan tanggung jawab, pendapat lain mengatakan bahwa tindakan Rodrigues bisa dibenarkan karena dia tidak mencari kebanggaan untuk kuat menderita. Pendapat ini menganggap bahwa Rodrigues telah sombong bila bersikeras untuk bertahan dengan tidak menginjak fumie. Dia sombong karena merasa mampu bertahan untuk tidak murtad. Bila dia tetap melakukannya, kesombongannya justru akan membuat lima orang mati. Patrick Malone berpendapat,

In the same way [as Peter did in John 21], Fr. Rodrigues no longer seeks to raise himself up and find Jesus in majesty, or in a beautiful endurance of suffering, but in the face of a man who is "sunken and utterly exhausted." He now sees his weakness and knows what it is to suffer not for the good Catholics in Japan, but for the corrupt, particularly Kichijiro because he has that same corrupt love. He no longer takes no pride in being able to identify with Jesus, because it is not something that he can do of his own power. Instead, Jesus can identify with him in his suffering. Instead of Fr. Rodrigues reaching up, Jesus reaches down. ${ }^{17}$

Malone hendak mengapresiasi tindakan Rodrigues. Menurutnya, Rodrigues dianggap mencontoh Petrus yang dipanggil kembali oleh Yesus di Yohanes 21. Kala itu Petrus tidak bersikeras untuk memenuhi tuntutan yang terlalu tinggi untuknya, yaitu mengasihi Yesus dengan kasih tanpa syarat (agapao). Ketimbang menyombongkan diri di hadapan Tuhan, Petrus mengaku bahwa dia hanya bisa mengasihi Yesus dengan kasih layaknya saudara (phileo). Dalam keotentikan

\footnotetext{
17 Patrick Malone, "Weak Love and Moral Culpability in Shusaku Endo's Silence," Catholic Stand, 28 Januari 2017, diakses 7 Mei 2017, http://www.catholicstand.com/weak-love-moral-culpability-shusaku-endossilence/.
} 
Petrus, Yesus mendekatkan diri pada Petrus dengan menurunkan standar-Nya. ${ }^{18}$ Rodrigues melakukan hal serupa.

Apresiasi Malone nampaknya menjawab dua pertanyaan dilema etis di atas. $(\alpha)$ Tuntutan moral mana yang lebih utama di antara yang lain? Tuntutan untuk merendahkan dirinya dengan berhenti merasa kuat di hadapan Tuhan. ( $\beta$ ) Tindakan apa yang secara efektif dapat mewujudkan tuntutan moral tersebut? Tindakan untuk menyerah dan menginjak fumie. Dengan kedua jawaban di atas, Rodrigues melakukan hal yang benar.

Sayangnya, dukungan terhadap Rodrigues ini tidak memperhatikan kondisi. Dalam menolak menginjak fumie, Rodrigues tidak berusaha bertahan dalam tekanan iman demi pengakuan orang lain atau demi pengakuan Tuhan. Dalam satu adegan, seketika sebelum Rodrigues menginjak fumie, Bapa Ferreira berkata, "Lupakan penghakiman gereja!" Akan tetapi Rodrigues tidak menggubrisnya, sebab yang membuat Rodrigues enggan menginjak fumie bukanlah penghakiman gereja. Rodrigues tidak ingin mengkhianati Tuhan yang ia kasihi. Rodrigues juga tak ingin gerakan misi berhenti.

Lagipula, bila Malone mengapresiasi kerendahan hati Rodrigues yang tidak menganggap dirinya mampu bertahan dalam pengakuan iman, yang kemudian membuatnya mengambil keputusan untuk menginjak fumie, pujian juga harus diberikan bila Rodrigues berkata, "Saya tidak bisa menginjak fumie." Penderitaan terbesar Rodrigues bukanlah saat di mana dia bertahan dengan imannya, melainkan ketika dia menginjak fumie. Martin Scorsese memberikan efek "suara Tuhan" yang didengar Rodrigues dari fumie beberapa detik sebelum dia menginjaknya. Suara tersebut muncul demi menghibur Rodrigues. Suara tersebut menggambarkan apa yang dirasakan Rodrigues. Batang tembaga tersebut berkata, "Come ahead now. It's alright. Step on Me. I understand your pain. I was born into this world to share men's pain. I carried this cross for your pain. Your life is with Me, now. Step." 19 Dari sini terlihat bahwa rasa sakit terbesar justru ada pada tindakan menginjak fumie, karena itu dia butuh penghiburan dari "Yesus."

Dengan demikian, kedua pertanyaan di atas bisa diajukan ulang. $(\alpha)$ Tuntutan moral mana yang lebih utama di antara yang lain? Tuntutan untuk merendahkan dirinya dan berhenti merasa kuat di hadapan Tuhan (masih sama dengan standar Malone). ( $\beta$ ) Tindakan apa yang secara efektif dapat mewujudkan tuntutan moral tersebut? Sangat jelas bahwa menginjak fumie adalah penderitaan terberat

\footnotetext{
18 Ibid.

${ }^{19}$ Dikutip dari menit 02:17:26 - 02:18:09.
} 
Rodrigues. ${ }^{20}$ Tindakan paling efektif untuk mewujudkan tuntutan pada pertanyaan $\alpha$ adalah: menahan diri menginjak fumie dengan cara diam saja dan berkata, "Saya tidak bisa menginjak fumie. Saya tidak mampu menanggung penderitaan sebesar itu." Alhasil, dengan perspektif Malone pun, Rodrigues melakukan hal yang salah, karena tetap mau menanggung penderitaan besar itu. Standar yang dipakai Malone untuk memuji Rodrigues akhirnya juga bisa dipakai untuk mempersalahkannya.

Ketiga, jawaban lainnya mengatakan bahwa memang Rodrigues terjebak dalam dilema etis yang tak terelakkan. Pilihannya menjadi tanggung jawabnya. Akan tetapi dia tidak dipersalahkan dengan tuntutan moral yang ditinggalkannya. Pandangan ini disebut absolutisme bertingkat atau juga kadang disebut pendekatan kebaikan tertinggi (greater good). Absolutisme bertingkat menganggap bahwa Tuhan tidak memerintahkan manusia untuk menghindari kejahatan, melainkan melakukan kebaikan. Karena itu, dalam dilema etis sekalipun, manusia hanya akan berhadapan dengan dua tuntutan moral yang berupa perbuatan baik yang saling berkonflik. Manusia tidak akan pernah berhadapan dengan dua perbuatan jahat yang harus dibindari. Sebab bila demikian, maka itu artinya Allah memaksa manusia untuk berbuat dosa, meskipun dosa yang dilakukan bukanlah dosa paling besar yang ada pada situasi saat itu. Manusia, dalam sebuah dilema etis, hanya akan berhadapan dengan dua perintah berbuat baik yang harus dipilih. ${ }^{21}$ Mari terapkan pertanyaan $\alpha$ dan $\beta$ kepada usulan yang ketiga ini.

$(\alpha)$ Tuntutan moral mana yang lebih utama di antara yang lain? Dalam kasus Rodrigues, Philip Quinn mendasarkan etika kasih Kristen pada dua perintah yang sama pentingnya, yaitu mengasihi Allah secara total dan mengasihi manusia seperti diri sendiri. ${ }^{22}$ Dalam situasi ini, kedua perintah (baca: tuntutan moral) yang sama pentingnya itu justru sedang berkonflik. Menurut Geisler, mengasihi Allah lebih penting dari mengasihi manusia. "Dengan jelas Yesus menegaskan bahwa 'yang pertama' dan 'terutama' itu melebihi 'yang kedua,' bahwa mengasihi Allah adalah yang paling penting, dan kemudian mengasihi sesama." 23

\footnotetext{
${ }^{20}$ Dengan suara dari fumie itu Rodrigues mendapatkan penghiburan bahwa rasa sakit yang sangat berat tersebut akan ditanggung oleh Yesus yang sudah memikul salib bagi dia. Ketimbang diam saja, Rodrigues diminta untuk berani mengambil rasa sakit itu. Dalam film, Rodrigues dianggap berhasil bukan karena kerendahan hatinya yang tidak mengambil penderitaan yang tidak mampu dia tanggung, melainkan karena dia telah rela menderita dengan menginjak fumie.

${ }^{21}$ Geisler, Etika Kristen, 116-139. Bdk. Geisler dan Feinberg, Filsafat dari Perspektif Kristiani, 474-479.

${ }^{22}$ Quinn, "Tragic Dilemmas, Suffering Love, and Christian Life," 111.

${ }^{23}$ Geisler, Etika Kristen, 120.
} 
Bila demikian, mencari tuntutan moral mana yang lebih utama ketimbang yang lain bukan perkara sulit. Akan tetapi, Quinn menganggap bahwa keduanya setara. Walaupun kedua perintah itu disebutkan berurutan, "it does not seem to [Quinn] that Jesus says or implies that the second is to be subordinated to the first or that the first would override the second in case of conflict. See also Mark. 12:29-33, in which Jesus first orders and then conjoins the two parts of the Great Commandment." 24

Dalam menentukan mana peraturan lebih tinggi, memang benar bahwa hanya Allah saja yang mampu menentukan. Manusia hanya mencari apa yang diutamakan oleh Allah melalui apa yang difirmankan-Nya. ${ }^{25}$ Akan tetapi, memegang firman-Nya, Alkitab, sebagai penuntun untuk mengetahui mana tuntutan moral yang lebih tinggi tidak semudah melihat daftar belanja. Fakta bahwa ada dua tuntutan moral yang nampak setara di atas membuat pembaca Alkitab_-yang juga pengambil keputusan moral—menggali kembali data-data demi penentuan keutamaan. Geisler memberikan setidaknya lima standar dalam Alkitab.

1. Allah lebih tinggi daripada manusia (Mat. 10:37).

2. Keluarga seseorang lebih penting daripada keluarga orang lain (1Tim. 5:8).

3. Manusia lebih bernilai daripada benda (Mrk. 8:36) ${ }^{26}$

4. Menaati Allah lebih tinggi dari menaati pemerintah.

5. Belas kasihan lebih tinggi dari kejujuran. ${ }^{27}$

Dengan kelima tesis standar moral akitabiah di atas, seseorang akan dengan mudah melihat mana yang lebih penting dari pada yang lain. Akan tetapi, sepertinya tesis moral yang pertama menemui bantahan.

Pasalnya, Matius hanya menuliskan, "barangsiapa mengasihi bapa atau ibunya lebih dari pada-Ku . . . ia tidak layak bagi-Ku" (Mat. 10:37). Seperti yang sempat disampaikan di atas, bentuk mengasihi bisa apa saja. Dalam situasi Rodrigues, Ferreira telah memberikan interpretasi baru bahwa, "Bila Yesus ada di sini, dia juga akan murtad demi menyelamatkan nyawa mereka" (10). Mengasihi Allah bisa diwujudkan dengan meniru apa yang akan dilakukan-Nya. Mengasihi Allah juga berarti mengasihi manusia (tawanan) ketimbang diri sendiri.

Penentuan akan mana tuntutan moral yang paling tinggi dari antara kedua great commandment memang cukup sulit. Terlepas dari itu, penulis mencoba memberikan usulan lain bahwa kedua tuntutan moral

\footnotetext{
${ }^{24}$ Quinn, “Tragic Dilemmas, Suffering Love, and Christian Life," 111.

25 Geisler dan Feinberg, Filsafat dari Perspektif Kristiani, 478.

${ }^{26}$ Ibid.

${ }^{27}$ Geisler, Etika Kristen, 125-126.
} 
dapat dilakukan dalam satu tindakan sekaligus. Dalam bagan di atas penulis telah menunjukkan bahwa tindakan moral 1 dapat dikerjakan dengan dua pilihan tuntutan moral (tuntutan 2 atau 3). Akan tetapi, penulis menganggap bahwa kedua tuntutan moral tersebut secara simultan bisa mendasari satu tindakan moral. Pertanyaannya, di antara menginjak fumie atau tidak, $(\beta)$ tindakan apa yang secara efektif dapat mewujudkan tuntutan moral tersebut? Sepertinya, dengan menginjak fumie Rodrigues telah mengasihi sesamanya, karena dengan itu kelima tawanan diselamatkan. Dengan itu juga Rodrigues mengasihi Tuhan yang juga, dianggapnya, akan melakukan hal yang sama ketika ada dalam posisi Rodrigues, yaitu seperti apa yang Bapa Ferreira katakan: "Dia juga akan murtad demi menyelamatkan kelima tawanan." Rodrigues mengasihi Tuhan dengan meniru tindakan Kristus yang telah didefinisikan ulang. Rodrigues mengasihi Tuhan dengan menaati perintah untuk mengasihi sesama. Rodrigues juga mengasihi Tuhan dengan rela mengambil penderitaan ketika menginjak fumie.

\section{Tuntutan Religius dan Moralitas Umum}

Dilema etis tidak bisa dianggap selesai begitu saja. Pertimbangan untuk mengambil keputusan akan lebih kompleks bila konflik tuntutan moral didefinisikan ulang. Bila sebelumnya konflik tuntutan moral yang muncul adalah antara perintah untuk mengasihi Allah dan perintah untuk mengasihi sesama. Maka kali ini, Phillip Quinn memberikan gagasan yang bisa dijadikan opsi solusi keempat bagi pergumulan etis Rodrigues. Quinn menunjukkan bahwa ada konflik antara tuntutan religius yang berasal dari penguasa ilahi dengan tuntutan moralitas umum (ordinary morality). ${ }^{28}$ Menurutnya, kadangkala manusia diperhadapkan dengan dilema etis antara sebuah kewajiban agamawi, seperti perintah-perintah dalam Kitab Suci yang spesifik ditujukan kepada pemeluk agamanya, dengan etika yang bersifat umum, seperti tuntutan-tuntutan untuk tidak membunuh, tidak mencuri, dan yang lainnya.

Quinn melihat hal ini terjadi pada Abraham dan menyebutnya Kierkegaardian Conflict (KC). ${ }^{29}$ Dengan melihat cara Quinn menyelesaikan $\mathrm{KC}$, saya juga akan menerapkannya kepada dilema etis yang dialami Rodrigues. KC terangkum dalam deret proposisi sebagai berikut:

\footnotetext{
${ }^{28}$ Quinn, “Tragic Dilemmas, Suffering Love, and Christian Life,” 110-111.

29 Philip L. Quinn, "Moral Obligation, Religious Demand, and Practical Conflict," in Essays in Philosophy of Religion, ed., Christian B. Miller (Oxford: Oxford University Press, 2006), 83. Dia menyebut nama Kierkegaard karena Kierkegaardlah, dalam karyanya Fear and Trembling, yang pernah mengelaborasi ketaatan Abraham ketika diperintahkan untuk membunuh anaknya.
} 
(i) Allah memerintahkan Abraham untuk melakukan tindakan membunuh Ishak. Hal itu mengharuskan Abraham untuk membunuh Ishak. ${ }^{30}$

(ii) Ishak adalah anak kecil yang tidak bersalah. Itu mengharuskan Abraham untuk menahan diri membunuh Ishak.

(iii) Keharusan untuk Abraham menahan diri membunuh Ishak, di mana itu diniscayakan oleh keadaan bahwa Ishak adalah anak yang tak bersalah, tidak bisa digantikan oleh tindakan lain (state of affair).

(iv) Abraham tidak mungkin secara fisik melakukan sekaligus tidak melakukan itu bersamaan. ${ }^{31}$

Dari sini terlihat bahwa (iv) menunjukkan adanya konflik tindakan moral. Membunuh dan tidak membunuh tidak bisa dilakukan sekaligus. Abraham harus memilih salah satu di antaranya. Dasar dari membunuh adalah (i) Allah sendiri yang memerintahkan Abraham untuk membunuh, sedangkan dasar dari tidak membunuh adalah (ii), di mana keadaan bahwa Ishak adalah anak yang tak bersalah mengharuskan Abraham menahan diri untuk membunuh. Proposisi (i) dan (ii) adalah bentuk konflik dua tuntutan moral. Proposisi (i) menunjukkan bahwa tuntutan itu berasal dari Tuhan langsung. Sedangkan proposisi (ii) menunjukkan bahwa tuntutan itu berasal dari nilai moral secara umum.

Quinn mencoba menyelesaikan ini dengan mengatakan bahwa kadang-kadang tuntutan religius tidak selalu bersifat moral (nonmoral), dalam kasus Abraham adalah membunuh anaknya sendiri. Karena tuntutan religius itu bersifat non-moral, maka itu tidaklah bisa mengatasi urgensi dari supremasi tuntutan moral, yang jelas lebih tinggi, di mana itu diwujudkan dengan tindakan untuk menahan diri membunuh seorang anak yang tak bersalah. KC yang berupa konflik antara tuntutan religius non-moral dengan tuntutan moral bisa saja terjadi. ${ }^{32}$ Mengapa itu terjadi? Mengapa manusia seringkali berat untuk menghindar dari tuntutan religius, bahkan yang bersifat non-moral? Sederhananya, mengapa tindakan Abraham yang pada akhirnya mau

${ }^{30}$ Ini adalah satu contoh lagi mengenai perbedaan antara tuntutan moral dan tindakan moral. Perintah Allah untuk membunuh Ishak adalah tuntutan moral, sedangkan tindakan membunuh Ishak adalah tindakan moral.

31 Quinn, "Moral Obligation, Religious Demand, and Practical Conflict,"

83.

32 Quinn, "Moral Obligation, Religious Demand, and Practical Conflict," 
membunuh anaknya bisa dianggap benar? Quinn memberikan dua tesis penting untuk menjelaskan mengapa $\mathrm{KC}$ bisa terjadi.

Q1. Kebaikan ilahi menjelaskan mengapa perintah-Nya menciptakan tuntutan yang harus dipenuhi.

Q2. Fakta bahwa kebaikan ilahi memiliki komponen nonmoral menjelaskan mengapa kadang-kadang $\mathrm{KC}$ terjadi, di mana tuntutan non-moral tersebut berkonflik dengan tuntutan moral. ${ }^{33}$

Kebaikan ilahi yang berada dibalik tuntutan religius non-moral itulah yang membuat manusia sulit meninggalkan tuntutan religius ketika berhadapan dengan tuntutan moral. Ada kebaikan ilahi yang tertanam dalam perintah membunuh Ishak, di mana itu akhirnya berkonflik dengan tuntutan moral.

\section{Sikap Penulis Terhadap Usulan KC Quinn}

Adanya asumsi tentang kebaikan ilahi menunjukkan bahwa argumen Quinn didasarkan pada pandangan Divine Command Theory. Teori ini menjelaskan bahwa Allah adalah "moral authority, in the sense not merely that he is a reliable source of information about moral matters but that he determines morality. The moral status of actions depends upon God." 34 Teori ini mengasumsikan bahwa Allah berada di balik semua tuntutan moral. Sebuah tuntutan dikatakan bermoral karena Allah sendiri yang memerintahkannya. Aquinas, dalam Summa Theologica, mengatakan bahwa "We have now to consider the extrinsic principles of acts. Now the extrinsic principle inclining to evil is the devil, ... [b] ut the extrinsic principle moving to good is God." 35 Kebaikan tidak ada secara intrinsik dalam sebuah tuntutan moral. Sebuah tuntutan moral dikatakan baik karena ada kebaikan Allah di balik itu. Teori ini, akhirnya, mengatakan bahwa keberadaan Allah menjadi penjelasan utama mengapa sebuah tuntutan moral punya keharusan untuk dijalankan. Paul Copan dan Matthew Flannagan memberikan ilustrasi bahwa natur dari air dapat dijelaskan dengan mengidentifikasikannya dengan $\mathrm{H} 2 \mathrm{O}$. Adanya $\mathrm{H} 2 \mathrm{O}$ dalam sebuah entitas tersebut menyebabkan dia harus disebut air, bukan logam. ${ }^{36}$

\section{${ }^{33}$ Ibid.}

34 Edward R. Wierenga, The Nature of God: An Inquiry Into Divine Attributes, Cornell Studies in the Philosophy of Religion (Ithaca: Cornell University, 1989), 215.

35 Thomas Aquinas, Summa Theologica, trans., Fathers of English Dominican Province (Perrysburg: Benzinger Bros, 1947), [FS] (QQ. 90), 1328.

36 Paul Copan, Did God Really Command Genocide?: Coming to Terms With The Justice of God (Grand Rapids: Baker, 2014), 149. 
Dengan kata lain, yang terutama dalam sebuah tuntutan moral adalah kebaikan ilahi itu sendiri. Kebaikan ilahi itulah yang menyebabkan manusia ingin mengejarnya. Quinn sendiri mengakui bahwa "for the sake of argument, let it be granted what divine commands would indefeasibly impose requirements and that some of these requirements would be nonmoral, religious requirements." ${ }^{37}$ Dengan kata lain, ada kebaikan ilahi yang "ditanam" Allah pada perintah religius yang akhirnya mengharuskan manusia untuk menaatinya. Quinn akhirnya menganggap bahwa adalah mungkin bila seseorang dibenarkan memilih tuntutan religius bila dia benar-benar berada dalam $\mathrm{KC}^{38}$ Abraham, contohnya, dibenarkan karena dia memilih untuk taat pada tuntutan religius, sebab tuntutan non-moral tersebut, yaitu perintah untuk membunuh Ishak, terdapat kebaikan ilahi yang ingin dia kejar, melebihi tuntutan moral pada umumnya, yaitu tuntutan tidak membunuh seorang anak tak bersalah.

Bila saya mengaplikasikan pandangan ini dalam kasus Rodrigues, maka Rodrigues bisa dibenarkan bila menolak untuk menginjak fumie hanya jika dia benar-benar berada dalam KC. Faktanya, KC terjadi pada Rodrigues karena tuntutan religius yang menimpanya, yaitu perintah untuk mengakui Yesus di depan manusia (Mat. 10:32-33; Luk. 12:8-9), diperintahkan karena ada kebaikan ilahi di baliknya walaupun itu bersifat non-moral-asumsi divine command theory - ketika tuntutan religius itu juga berhadapan dengan tuntutan moral, yaitu mengasihi sesama dengan cara menyelamatkan kelima tawanan. ${ }^{39}$ Rodrigues dengan dasar teori ini tetap dibenarkan bila dia akhirnya memilih untuk tidak menginjak fumie. Rodrigues dibenarkan dalam hal itu karena dia lebih memilih untuk mengejar kebaikan ilahi di balik tuntutan religius non-moral yang dihadapinya.

Bagi penulis, dasar meta-etika divine command theory membuat pilihan etis ini sangat koheren. Akan tetapi, dasar itu juga menjadi bumerang. Sebab pembenaran tindakan Rodrigues dalam menolak menginjak fumie hanya muncul dari orang-orang pemegang divine command theory. Penjelasan filosofis yang sangat panjang masih dibutuhkan untuk menyelesaikan dilema Euthyphro yang muncul ribuan tahun silam. ${ }^{40}$ Penjelasan itulah yang nantinya menentukan

37 Quinn, "Moral Obligation, Religious Demand, and Practical Conflict," 86. Quinn menggunakan istilah requirements untuk merujuk pada tuntutan moral.

38 Ibid.

39 Dengan ini saya hendak mengatakan bahwa tuntutan religius berupa pengakuan akan Kristus di hadapan manusia tidak dianggap sebagai tuntutan moral. Namun, kebaikan ilahi yang ada di balik tuntutan religius tersebut membuatnya menjadi lebih penting ketimbang tuntutan moral pada umumnya.

${ }^{40}$ Dilema Euhyphro (Euthyphro dilemma) adalah sebuah dilema yang muncul dalam percakapan Socrates dan Euthyphro dalam tulisan Plato, Euthyphro. 
apakah divine command theory benar atau tidak. Ini layaknya ingin membangun menara pencakar langit pada fondasi yang belum diketahui apa bahan dasar fondasinya.

\section{Penutup}

Saya memang tidak memberikan konklusi pasti mengenai dilema etis dalam film ini. Apa yang saya lakukan adalah menelaah masalah di dalamnya. Diharapkan ini dapat membuka pemikiran pembaca dan membuat pembaca menyadari bahwa ini bukan masalah yang mudah. Apa yang bisa saya berikan akhirnya hanyalah sebuah apresiasi terhadap film ini. Silence telah berhasil membawa penontonnya melihat pergumulan iman dan etika yang sangat mendalam. Silence membuat penontonnya, termasuk saya, menggumulkan kembali apa artinya menjadi murid Kristus dan apa artinya menjadi serupa dengan Kristus. Shusaku Endo, pengarang novelnya, telah berhasil membawa saya menyelami spiritualitas Kristen yang mendalam. Tak salah bila Philip Ryken memberikan apresiasi dengan kalimatnya demikian: ${ }^{41}$

The story of Father Rodrigues mirrors the calling of the church in a fallen world. As we move from expected triumph to the suffering that comes through experience, we desperately need a theology of the cross. We need to see the face of a Savior who is not only triumphant and exalted, but also crucified and humiliated.

\section{Tentang Penulis}

Abel K. Aruan adalah mahasiswa S.Th tingkat akhir STT Seminari Alkitab Asia Tenggara, menaruh minat di bidang filsafat dan teologi sistematika. Saat ini ia sedang menulis skripsi mengenai kritik transendental Herman Dooyeweerd.

\section{Daftar Pustaka}

Diceritakan bahwa Socrates bertanya pada Euthypro, "Is the pious loved by the gods because it is pious, or is it pious because it is loved by gods?" Ini menjadi dilema yang menghasilkan perdebatan yang panjang di kalangan pemikir meta-etika (lih. podcast William Lane Craig di ReasonableFaith.org, 21 Oktober 2008).

41 Philip Ryken, Reflecting Silence: Perspectives on Shusaku Endo's Masterpiece, Picador Modern Classic, (tanpa keterangan kota: The Clapham Group), 27, diakses di https://images.macmillan.com/folio-assets/readersguides/9781250082275RG.pdf. 
Aquinas, Thomas. Summa Theologica. Trans., Fathers of English Dominican Province. Perrysburg: Benzinger Bros, 1947.

Copan, Paul. Did God really Command Genocide? Coming to Terms with the Justice of God. Grand Rapids, Michigan: Baker Books, a division of Baker Publishing Group, 2014.

Frame, John M. The Doctrine of the Christian Life: A Theology of Lordship. Phillipsburg, N.J: P \& R Pub, 2008.

Geisler, Norman. Etika Kristen: Pilihan dan Isu Kontemporer. $2^{\text {nd }}$ ed. Malang: Literatur SAAT, 2015.

Geisler, Norman, dan Paul D. Feinberg. Filsafat dari Perspektif Kristiani. Terj. Gandum Mas. Malang: Gandum Mas, 2002.

Hoffecker, Andrew, dan Gary Scott Smith. Membangun Wawasan Dunia Kristen. Terj. Peter Suwadi Wong. Vol. 2. 2 vol. Surabaya: Momentum, 2014.

Quinn, Philip L. "Moral Obligation, Religious Demand, and Practical Conflict." In Essays in Philosophy of Religion. Ed., Christian B. Miller, 77-91. Oxford: Oxford University Press, 2006.

. "Tragic Dilemmas, Suffering Love, and Christian Life." In Essays in the Philosophy of Religion. Ed., Christian B. Miller, 92122. Oxford: Oxford University Press, 2006.

Ryken, Philip. Reflecting Silence: Perspectives on Shusaku Endo's Masterpiece. NA: The Clapham Group. Online Published. https://images.macmillan.com/folio-assets/readersguides/9781250082275RG.pdf.

Wierenga, Edward R. The Nature of God: an Inquiry into Divine Attributes. Cornell studies in the philosophy of religion. Ithaca: Cornell University, 1989.

\section{INTERNET}

Malone, Patrick. 'Weak Love and Moral Culpability in Shusaku Endo's Silence." Catholic Stand. 28 Januari 2017. Diakses 7 Mei 2017. http://www.catholicstand.com/weak-love-moral-culpabilityshusaku-endos-silence/.

Roys, Julie. "Why Are Christians Praising Scorsese's 'Silence'? (Movie Review)." Christian Post. 13 Januari 2017. Diakses 8 Mei 2017. http://www.christianpost.com/news/christians-praisingscorsese-silence-movie-review-172951/.

McCracken, Brett. 'Scorsese's 'Silence' Asks What It Really Costs to Follow Jesus." Christianity Today. 16 Desember 2016. Diakses 8 Mei http://www.christianitytoday.com/ct/2016/december-webonly/silence-whispers-loudly-of-christs-love.html? start $=2$. 